\title{
Detailed LRI for Assessment of Land Capability and Land Suitability of Amarapura-2 Micro-Watershed Using RS and GIS
}

\author{
N.L. Rajesh $^{1 *}$, U. Satishkumar ${ }^{2}$, I. Shankergouda ${ }^{3}$, S.N. Bhat ${ }^{1}$, K. Basavaraj ${ }^{1}$, \\ H.V. Rudramurthy ${ }^{1}$, K. Narayana Rao ${ }^{1}$, V. Rajesh ${ }^{1}$ and R. Meenkshi Bai ${ }^{1}$ \\ ${ }^{1}$ Department of Soil Science, ${ }^{2}$ Department of SWE, CAE, ${ }^{3}$ Director of Research, UAS, Raichur \\ - 584 104, Karnataka, India \\ *Corresponding author
}

\section{A B S T R A C T}

\begin{tabular}{|l|}
\hline Ke y w or d s \\
$\begin{array}{l}\text { Micro watershed, Land } \\
\text { Resources Inventory, } \\
\text { Land Capability, Land } \\
\text { Suitability, RS \& GIS }\end{array}$ \\
\hline Article Info \\
\hline $\begin{array}{l}\text { Accepted: } \\
16 \text { September } 2018 \\
\text { Available Online: } \\
10 \text { October } 2018\end{array}$ \\
\hline
\end{tabular}

A detailed land resources inventory (LRI) of Amarapura-2 micro watershed was carried out at 1:8000 scale for deriving land capability and crop suitability classes. The micro watershed is located between $77^{0} 8^{\prime}$ to $17^{0} 17^{\prime}$ North latitude and $77^{0} 10^{1}$ to $17^{0} 15^{1}$ East longitude of Lingasaguru taluk, Raichur district, Karnataka State, India. Twenty four soil phase units with eight soil series were identified through detailed soil resource study. Land capability subclasses in the study area were IIIes and IVes with limitations of soil erosion, texture, soil drainage, soil fertility and topography. Land suitability for five major horticultural crops of the area were evaluated and found that only the soil phase unit "MRLfC2" was marginally suitable with limitation of rooting condition (S3r) for Sapota, Jamun, Gauva and Custard apple. Rest all 23 soil phase units were not suitable for all the five crops including Mango. Soil phase unit-wise crop plan with suitable interventions for maximising the yield of field crops, horticultural crops, vegetables, millets and pulses were developed which is a part of improved implementation program in Amarapura-2 microwatershed under the World Bank funded Sujala-III project.

\section{Introduction}

There is a significant diversion of farmlands to non- agricultural uses, exerting further strain on the already shrinking land and water resources, affecting not only the productivity but also the sustainability of the resources. Wrong choice of crops, faulty agricultural practices, imbalance in use of fertilizer, lack of appropriate cropping pattern and choice of land use to exploit the full potentials of the resources by the farmer have greatly affected the productivity of land resources. The problems of ever-increasing population and increased competition for a variety of demands have induced tremendous pressure on shrinking land resources. It is, therefore, essential to assess the potential of available land in terms of its capability for proper land use planning (Kharche and Gaikawad 1993). In view of this, a systematic study has been made to assess land capability for better land use adjustments according to FAO (1990), in Amarapura-2 micro-watershed for efficient 
land utilization in North Eastern part of Karnataka state, India, under the World Bank funded Sujala-III watershed development program, which is being implemented by Watershed Development Department \& Dept. of Horticulture, Govt. of Karnataka.

\section{Materials and Methods}

Amarapura-2 micro-watershed is located in Lingasugur taluk of Raichur district, Karnataka state and having total area of 519.33 hectares lies between $77^{0} 8^{\prime}$ to $17^{0} 17^{\prime}$ North latitude and $77^{0} 10^{1}$ to $17^{0} 15^{1}$ East longitude of $508 \mathrm{~m}$ above mean sea level (MSL). Semi-arid climate prevails on Amarapura-2 micro-watershed and it belongs to North Eastern Dry zone of Karnataka state. The average rainfall of this region is 560.87 $\mathrm{mm}$ with a large spatial and temporal variability. Mean maximum and minimum temperatures are $33.82^{\circ} \mathrm{C}$ and $21.16^{\circ} \mathrm{C}$, respectively. The highest rainfall was received during the month of October $(138 \mathrm{~mm})$. The length of growing period, which indicates the availability of water for plant growth, is about 120 to 150 days in a year. It starts from $2^{\text {nd }}$ week of August to $2^{\text {nd }}$ week of November. The location of the study area furnished in Figure 1. Amarapura-2 is surrounded by Kalarhatti, Todki, Kalmalli and Chatra villages.

The detailed survey (at 1:8000 scale) of the entire micro-watershed was carried out in the year 2016, with the help of cadastral map (Fig. 2) overlaid on IRS LISS-IV merged Cartosat-1 imagery ( $2.5 \mathrm{~m}$ spatial resolution), through rapid traversing to cover up the soils at varying physiographic position. During the traverse, based on geology, drainage pattern, surface features, slope characteristics and land use, landforms and physiographic units were identified. The pedons were exposed and studied for their morphological properties following the standard procedure outlined (Anon., 1999). Soil series wise surface and subsurface characteristics of the soil profile and also the fertility status were analysed (Table 1a and 1b) using standard analytical procedures (Jackson, 1958). These results were used as input parameters to classify the Land capability and Land suitability for various horticultural crops.

\section{Results and Discussion}

\section{Soil classification}

Based on these soil-site properties of Amarapura-2 micro-watershed area was divided into different homogeneous units known as mapping/management units. Soil series identified under study were Bhogapur, Chatra, Chatra Tanda, Kalamalli, Kammarkhed, Kamarkhed tanda, Marali, and Vaykarnala (Fig. 3). These eight soil series obtained were found in three different landforms viz., upland, midland and lowland from very gentle sloping (1-3\%) to gentle sloping (3-5\%). The extent of area and distribution of these soil series were drawn and overlaid with cadastral map to get the $\mathrm{parcel} / \mathrm{survey}$ number wise soil information.

\section{Land capability classification}

Land capability classification is an interpretive grouping of soils mainly based on the inherent soil characteristics, external land features and environmental factors that limits the use of the land (Anonymous, 1961). Morphological features of soil units (Table 1a and 1b) are matched with the criteria for land capability classification (Sehgal, 1996). The land capability classification of mapping units and their extent in watershed is presented in Figure 3. Based on soil properties, the soils of Amarapur-2 micro-watershed of Lingasugur taluk have been classified as III and IV and the area under IIIes and IVes was 63 ha and 195 ha, respectively with limitations of texture, drainage, fertility and topography. 
Fig.1 Location map of the Amarapura-2 MWS
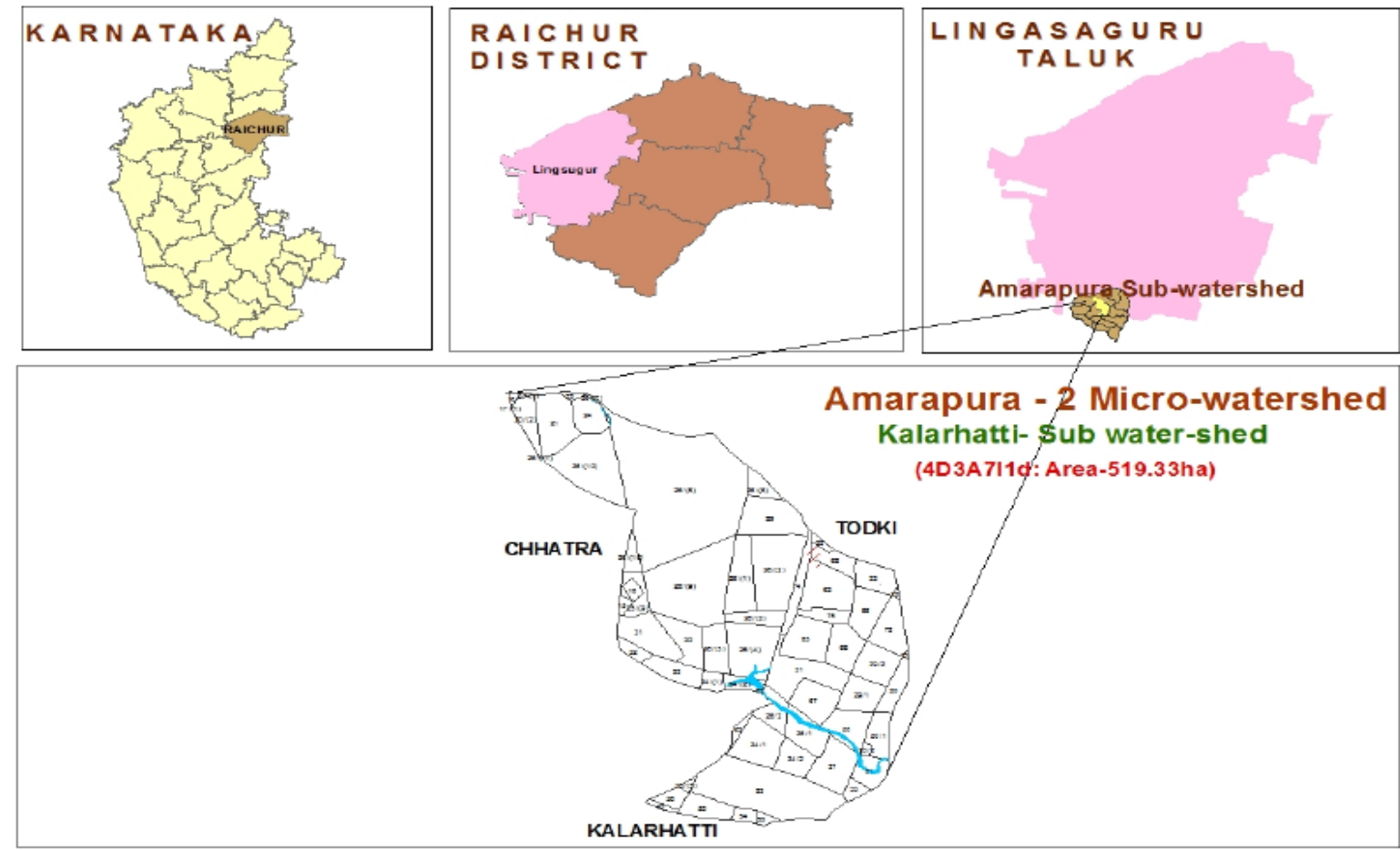

Fig.2 LISS IV merged Cartosat - I satellite imagery overlaid with cadastral map

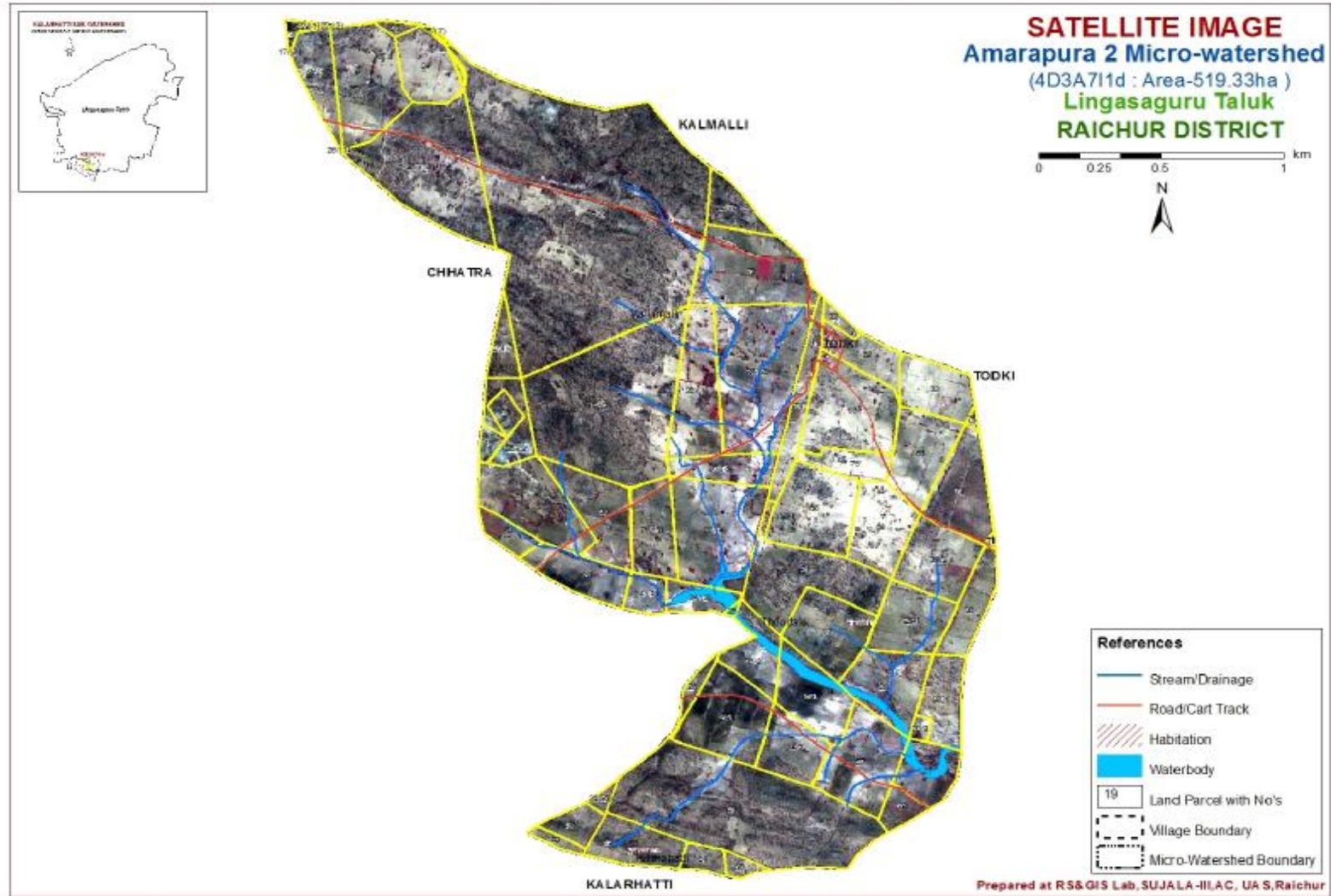


Fig.3 Soil mapping units of Amarapura-2 MWS

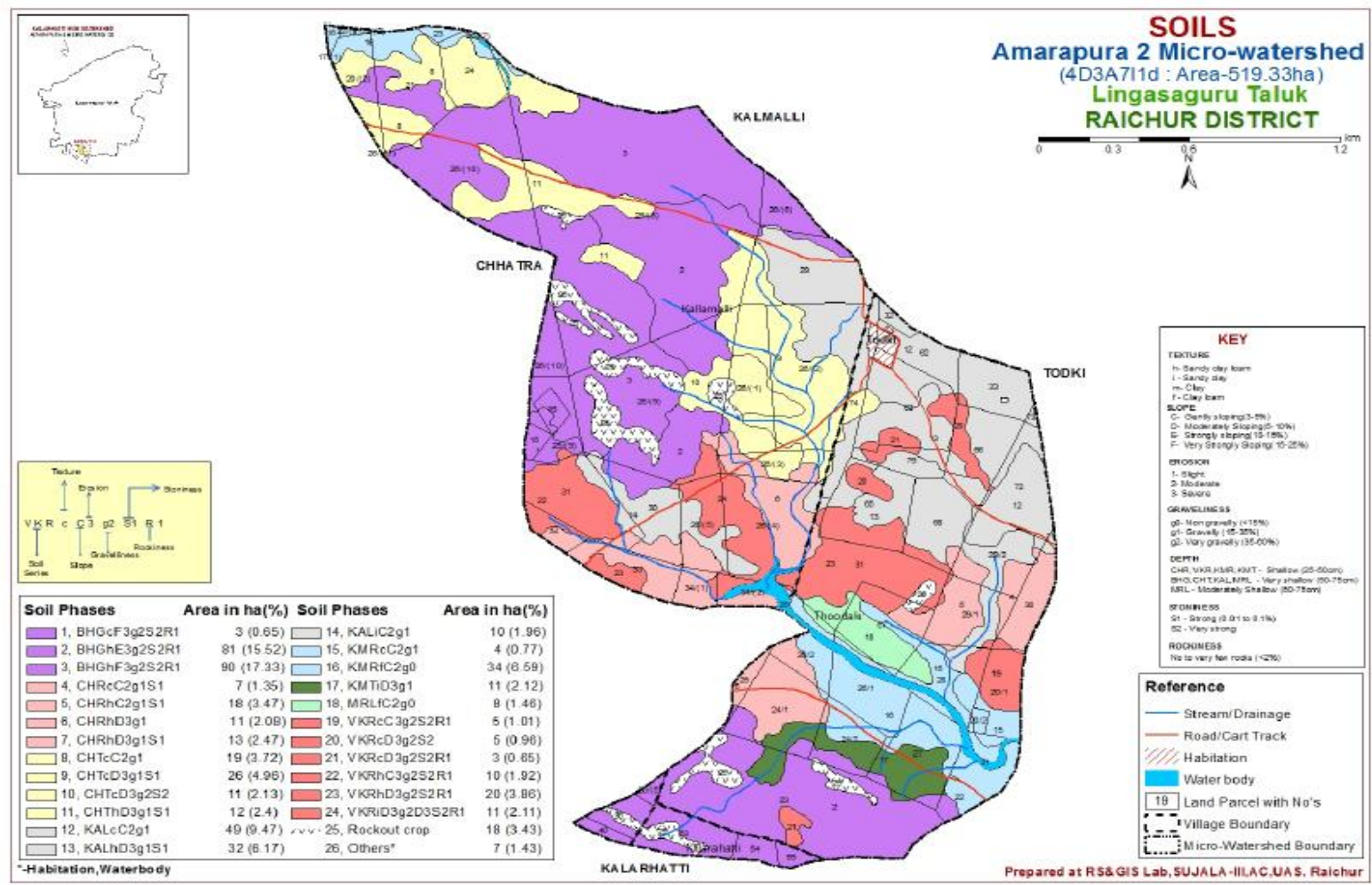

Fig.4 Land capability classification of soils in Amarapura-2 MWS

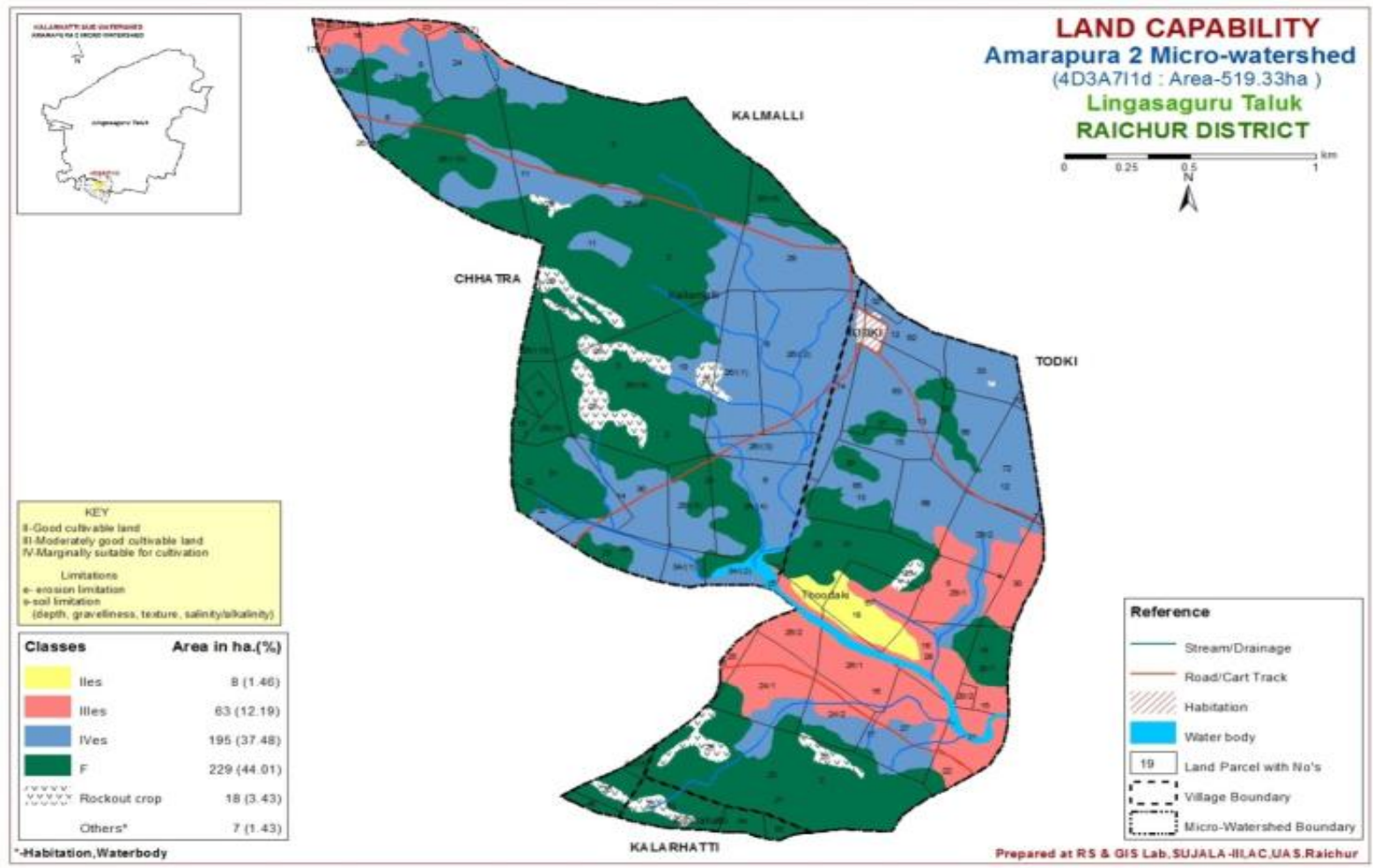


Fig.5 Crop suitability for mango in Amarapura-2 MW

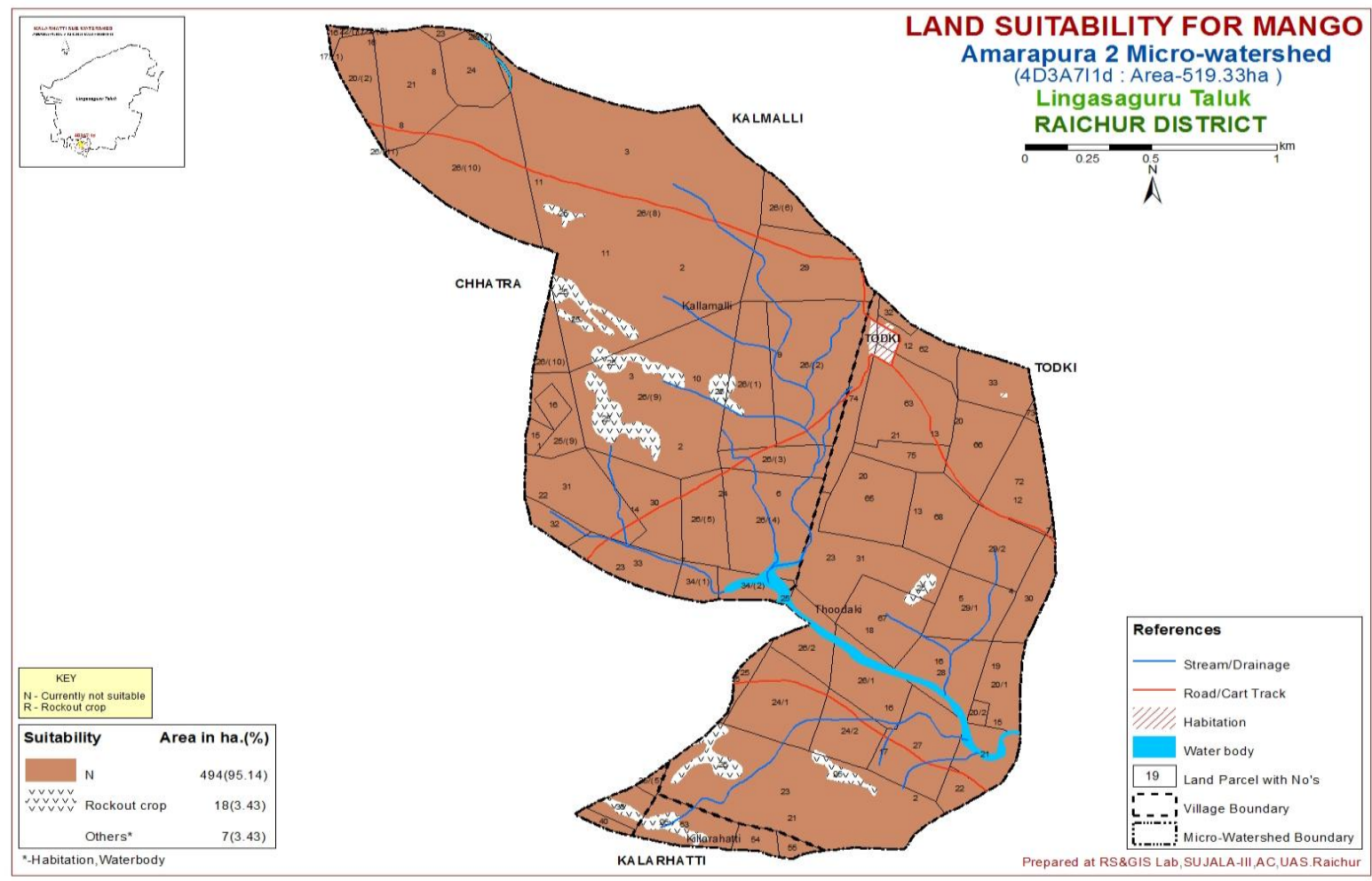

Fig.6 Crop suitability for sapota in Amarapura-2 MWS
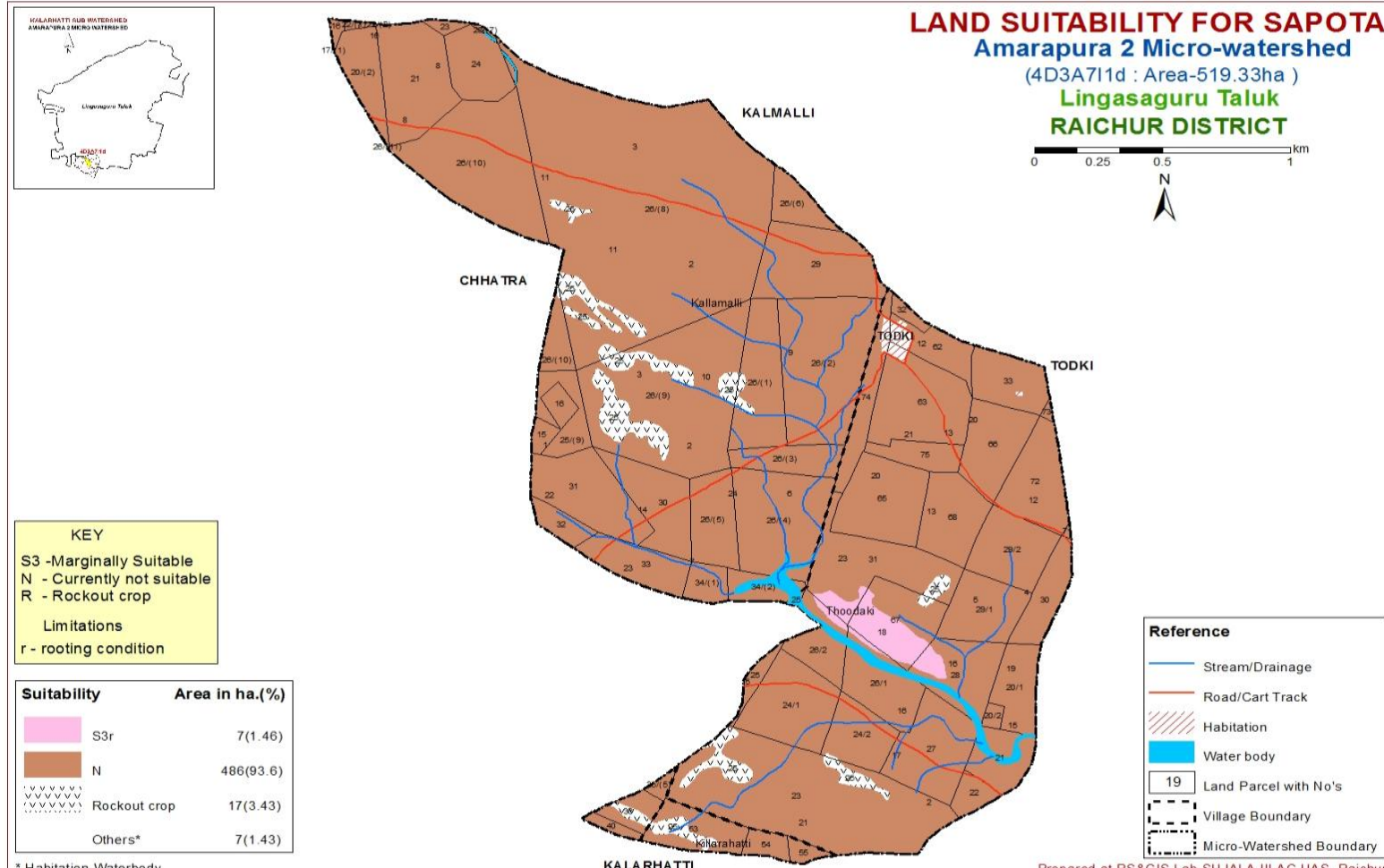

Habitation Waterbod 
Fig.7 Crop suitability for jamun in Amarapura-2 MW

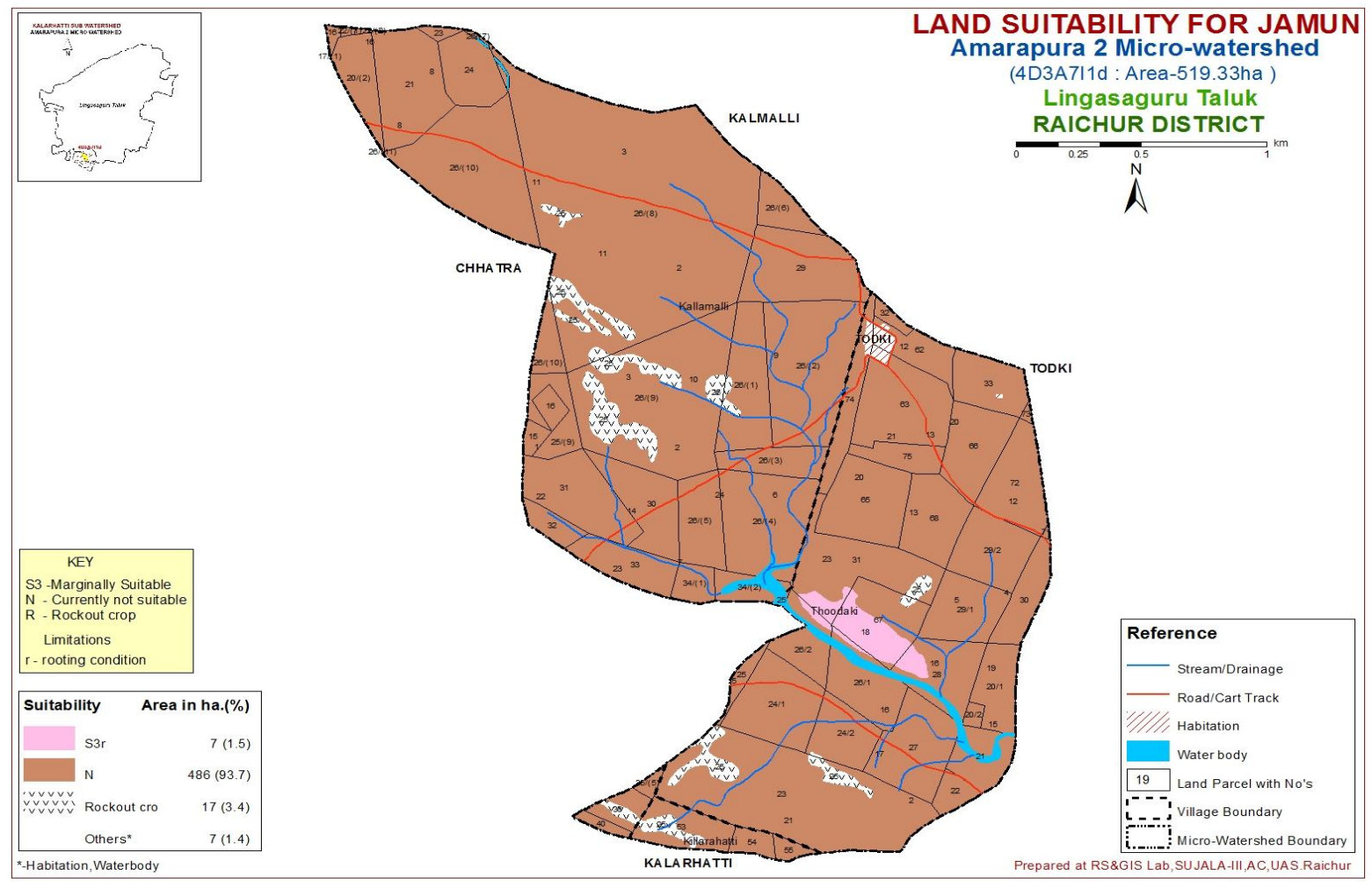

Fig.8 Crop suitability for guava in Amarapura-2 MWS

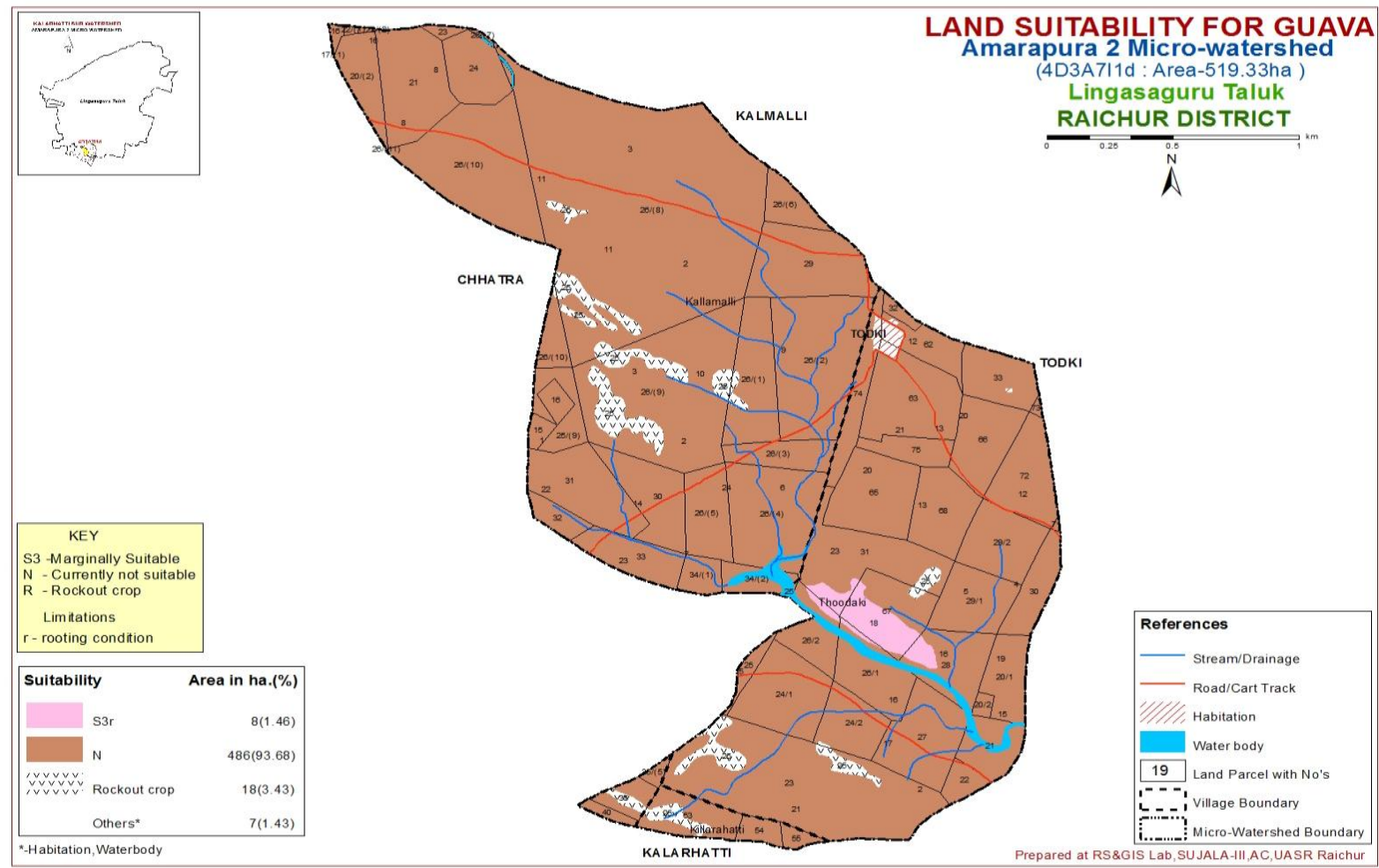


Fig.9 Crop suitability for custard apple in Amarapura-2 MWS

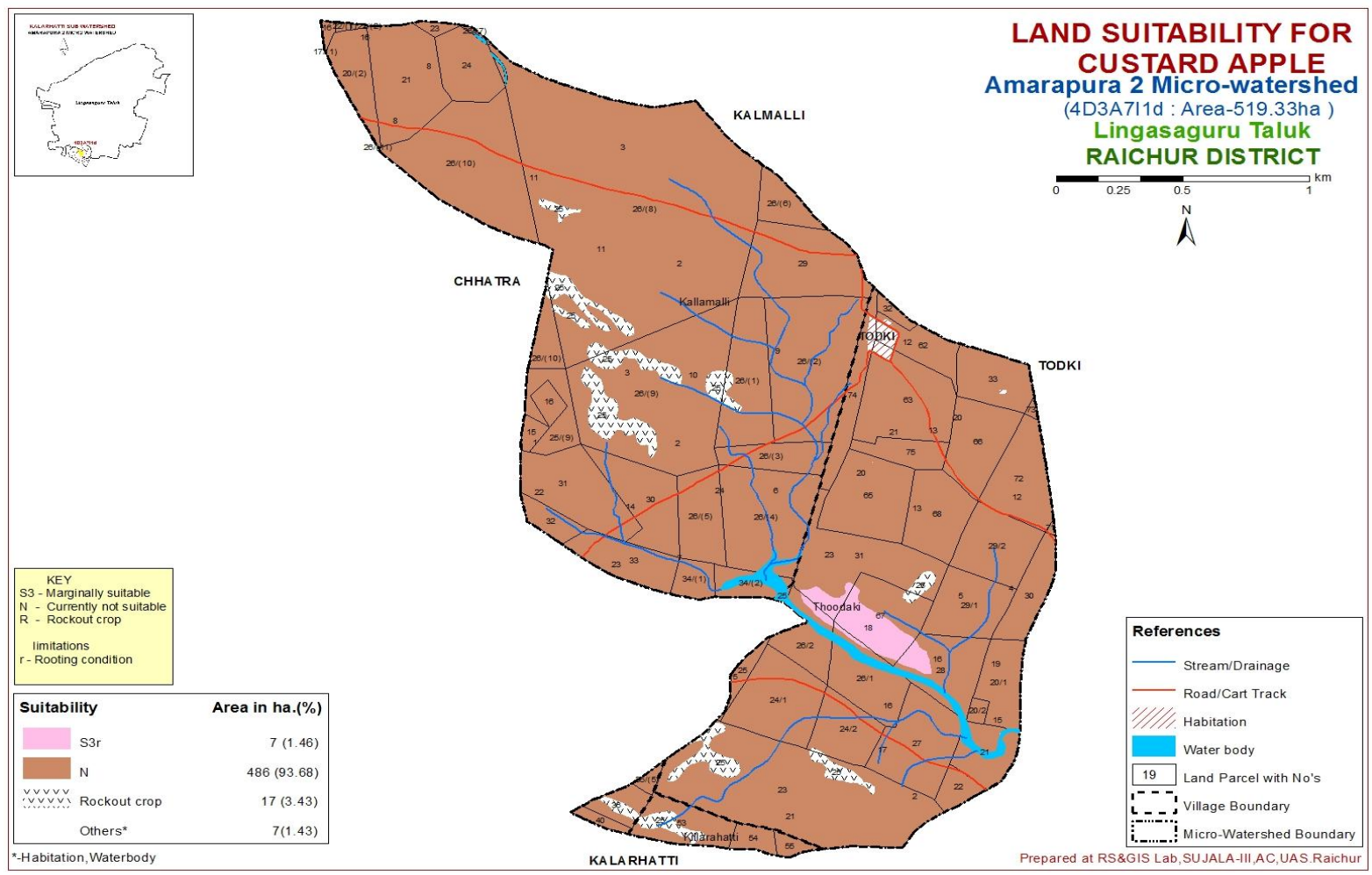

Fig.10 Land management unit in Amarapura-2 village

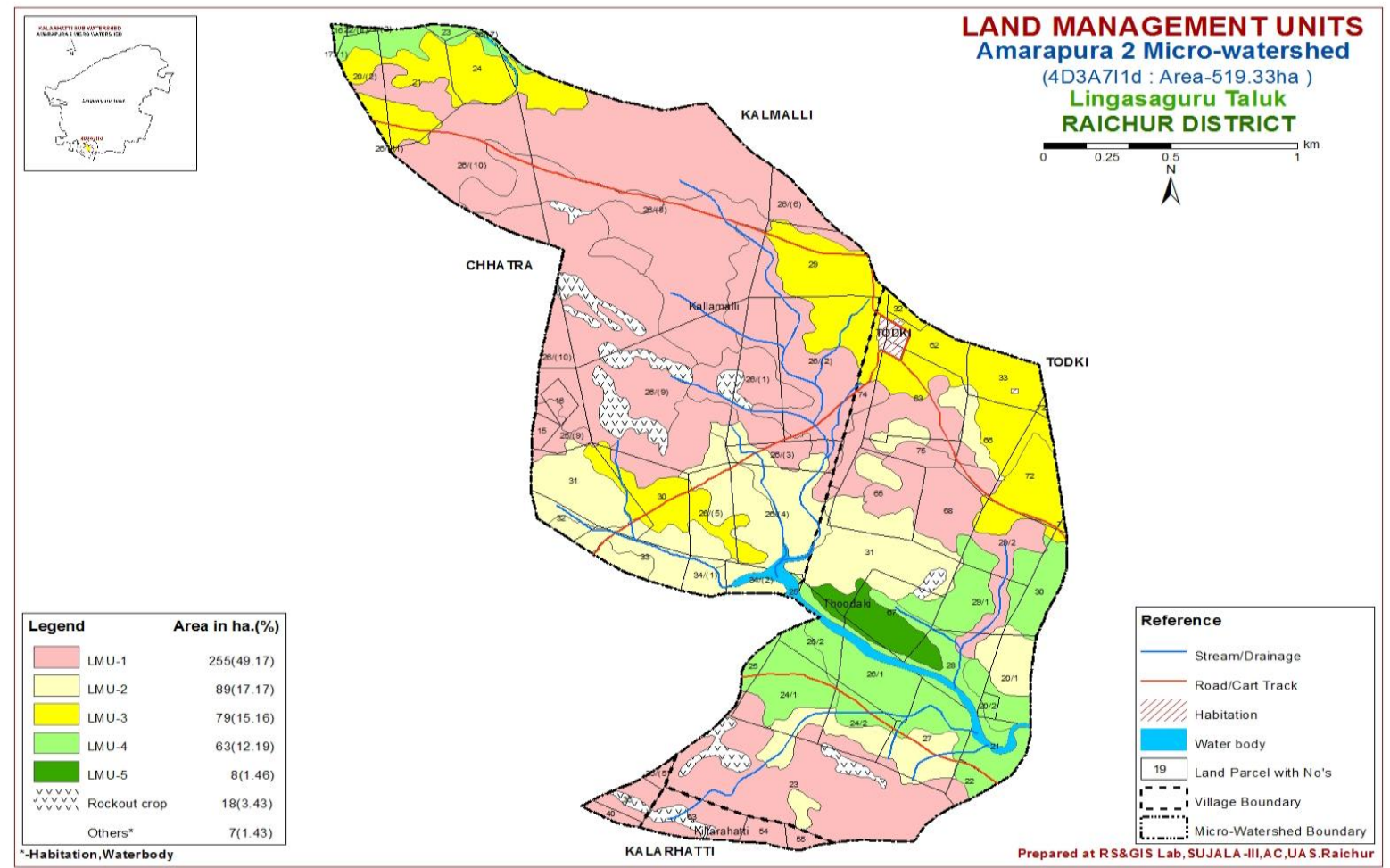


Table.1a Soil series and respective profile characterization in Amarapura-2 MWS

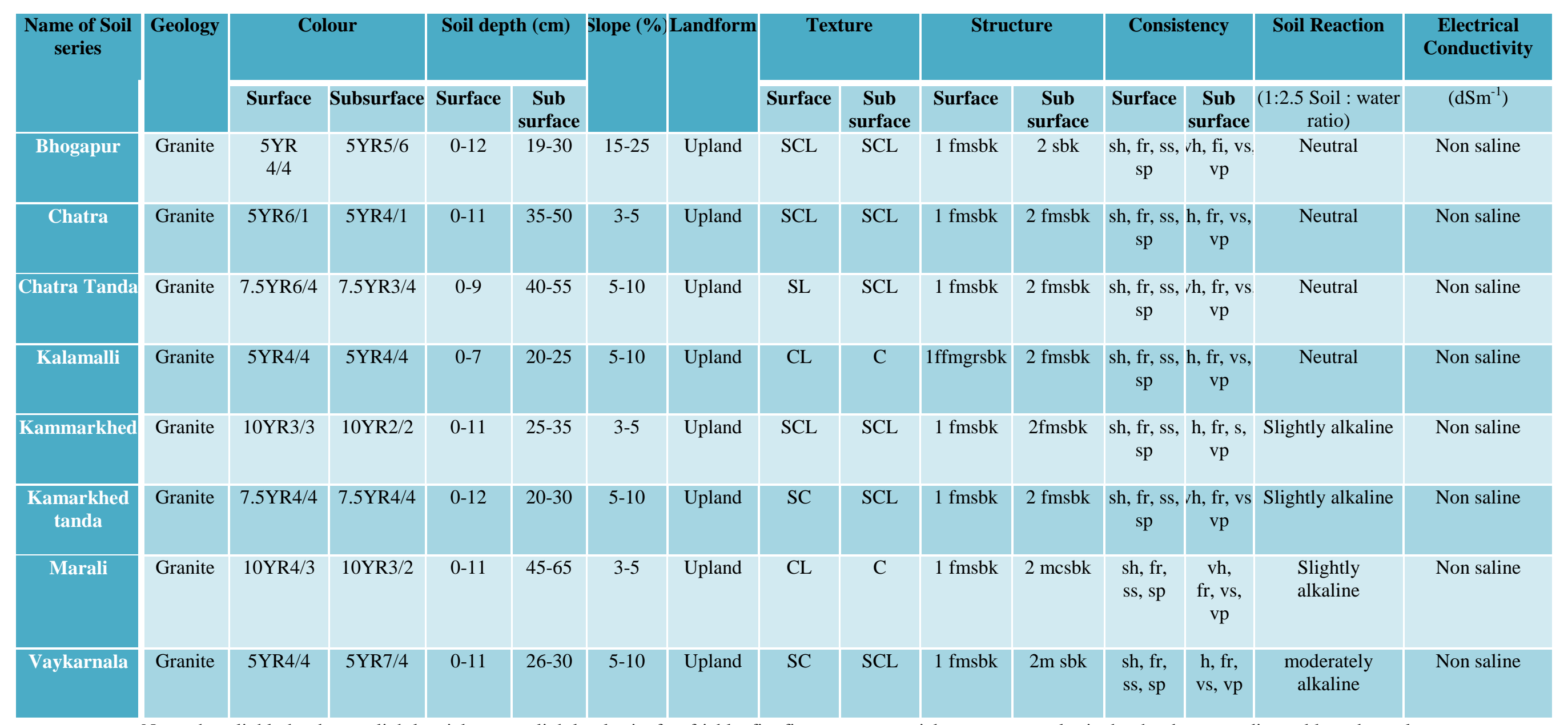

Note: sh - slighly hard, ss - slightly sticky, sp - slightly plastic, fr - friable, fi - firm, vs - very sticky, v p - very plastic, $\mathrm{h}$ - hard, $\mathrm{m}$ - medium, sbk -subangular blocky, abk-angular bloky, c - coarse, S-sand, C-clay, L-loam 
Table.3 Proposed crop plan for Amarapura-2 micro-watershed

\begin{tabular}{|c|c|c|c|c|c|}
\hline $\begin{array}{l}\text { Proposed } \\
\text { Land Use } \\
\text { Class }\end{array}$ & Soil Map Units & Survey Number & Field Crops & Horticulture Crops & Suitable Interventions \\
\hline LMU 1 & $\begin{array}{c}\text { BHGcF3g2S2R1, } \\
\text { BHGhE3g2S2R1, } \\
\text { BHGhF3g2S2R1,CHTcD3g1S1, } \\
\text { CHTcD3g2S2,CHThD3g1S1,KA } \\
\text { LhD3g1S1,Unmanaged }\end{array}$ & $\begin{array}{c}\text { Kalmalli: } \\
\text { Kalarhati26/10,26/8,26/11,26/6,26/9 } \\
, 25 / 9,26 / 1,26 / 2,26 / 3,35 / 5,29 / 2 \\
23,36,40,53,54,55,65,68,74\end{array}$ & $\begin{array}{l}\text { Open scrub with } \\
\text { thorny bushes, less } \\
\text { than } 10 \% \text { canopy }\end{array}$ & Nil & $\begin{array}{c}\text { Open scrub with thorny bushes, less } \\
\text { than } 10 \% \text { canopy }\end{array}$ \\
\hline LMU 2 & $\begin{array}{c}\text { CHRhD3g1, CHRhD3g1S1, } \\
\text { KMTiD3g1, VKRcC3g2S2R1, } \\
\text { VKRcD3g2S2,VKRcD3g2S2R1, } \\
\text { VKRhC3g2S2R1, } \\
\text { VKRhD3g2S2R1, } \\
\text { VKRiD3g2S2R1,Unmanaged }\end{array}$ & $\begin{array}{c}\text { Kalmalli:27,31,32,33,25,20/1,26/4, } \\
\text { Todki:31/434/1 }\end{array}$ & $\begin{array}{l}\text { All minor millets and } \\
\text { pulses }\end{array}$ & $\begin{array}{l}\text { Nil- as the soil depth is } \\
\text { very shallow, root zone } \\
\text { depth limitation }\end{array}$ & $\begin{array}{l}\text { Cultivation on raised bunds and ridge } \\
\text { furrows, with mulches and drip } \\
\text { irrigation system. Drip irrigation with } \\
\text { suitable soil and water conservation } \\
\text { measures. }\end{array}$ \\
\hline LMU 3 & $\begin{array}{l}\text { KALiC2g1,KALcC2g1,CHTcC2 } \\
\text { g1, Moderately managed }\end{array}$ & $\begin{array}{l}\text { Todki } 21,24,29,30,32,33 \\
62,66,72,73,20 / 2,26 / 5\end{array}$ & $\begin{array}{l}\text { All minor millets } \\
\text { and pulses }\end{array}$ & $\begin{array}{l}\text { Nil- as the soil } \\
\text { depth is very } \\
\text { shallow, root zone } \\
\text { depth limitation }\end{array}$ & $\begin{array}{l}\text { Cultivation on raised bunds and ridge } \\
\text { furrows, with mulches and drip } \\
\text { irrigation } \\
\text { System. Drip irrigation with suitable } \\
\text { soil and water conservation } \\
\text { measures. }\end{array}$ \\
\hline LMU 4 & $\begin{array}{c}\text { CHRcC2g1S1, CHRhC2g1S1, } \\
\text { KMRcC2g1, KMRfC2, } \\
\text { Moderately managed }\end{array}$ & $\begin{array}{c}\text { Todki: } 16,21,22,23,25,30 \\
20 / 1,20 / 2,22 / 1,22 / 2,26 / 7,17 / 1,26 / 2 \\
24 / 2\end{array}$ & $\begin{array}{l}\text { Soil crop; Green } \\
\text { gram, red gram, black } \\
\text { gram, til, sorghum, } \\
\text { other } \\
\text { minor short duration } \\
\text { crops }\end{array}$ & $\begin{array}{l}\text { Fruit crops: Mango, sapota, } \\
\text { Guava, Lime Jamun, Tamarind, } \\
\text { Jackfruit, Fig. } \\
\text { Veg: Beans, Bhendi, Drumstick, } \\
\text { Clusterbean, Curryleaf, Coriander } \\
\text { etc. Flower: Lilly, Merigold. }\end{array}$ & $\begin{array}{l}\text { Cultivation on raised bunds and ridge } \\
\text { furrows, with mulches and drip } \\
\text { irrigation system. Drip irrigation with } \\
\text { suitable soil and water conservation } \\
\text { measures. }\end{array}$ \\
\hline LMU 5 & $\begin{array}{l}\text { MRLfC2 } \mathrm{g} 0 \text {,moderately } \\
\text { managed }\end{array}$ & Thoodki, 67 & $\begin{array}{l}\text { Sole crop; sorghum, } \\
\text { Bajra, Navni, green } \\
\text { gram, cotton, red } \\
\text { gram, Bengal gram, } \\
\text { etc. major crop is red } \\
\text { gram and cotton } \\
\text { followed by sorghum }\end{array}$ & $\begin{array}{l}\text { Guava, custard apple, Tamarind, } \\
\text { sapota, jamun, Ber, } \\
\text { Veg: Onion, Tomato, Brinjal, } \\
\text { Chilli, Bhendi, lab lab, coriander, } \\
\text { and green leafs, curry leaf. } \\
\text { Flowers-Gaillardia, marigold, } \\
\text { Chrysanthemum, lilly }\end{array}$ & $\begin{array}{l}\text { Deep and wider size furrows, Drip } \\
\text { irrigation with suitable soil and water } \\
\text { Conservation measures Cultivation } \\
\text { on } \\
\text { raised bunds with mulches and drip. }\end{array}$ \\
\hline
\end{tabular}


Table.1b Soil fertility status of Amarapura-2 MWS

\begin{tabular}{|c|c|c|c|}
\hline \multirow[t]{2}{*}{ Parameters } & Low & Medium & High \\
\hline & \multicolumn{3}{|c|}{ Area (ha) } \\
\hline Organic carbon $(\%)$ & $129(24.88 \%)$ & $295(56.79 \%)$ & - \\
\hline Nitrogen (kg/ha) & $494(95.14 \%)$ & - & - \\
\hline Phosphorus (P205 kg/ha) & $221(97.34 \%)$ & $329(63.43 \%)$ & - \\
\hline Potassium (K20 kg/ha) & $494(75.11 \%)$ & - & - \\
\hline Sulphur (Kg/ha) & $154(21.61 \%)$ & $329(63.43 \%)$ & - \\
\hline Calcium (meq/100 g of soil) & - & - & $497(94.14 \%)$ \\
\hline Magnesium (meq/100 $\mathrm{g}$ of soil) & - & - & $497(94.14 \%)$ \\
\hline
\end{tabular}

Table.2 Crop suitability characteristics of Amarapura-2 MWS for land evaluation

\begin{tabular}{|c|c|c|c|c|c|}
\hline Profile unit & Mango & Sapota & Jamun & Guava & Custard apple \\
\hline BHGhF3g2S2R1 & $\mathrm{N}$ & $\mathrm{N}$ & $\mathrm{N}$ & $\mathrm{N}$ & $\mathrm{N}$ \\
\hline CHRhC2g1S1 & $\mathrm{N}$ & $\mathrm{N}$ & $\mathrm{N}$ & $\mathrm{N}$ & $\mathrm{N}$ \\
\hline KMTiD3g1 & $\mathrm{N}$ & $\mathrm{N}$ & $\mathrm{N}$ & $\mathrm{N}$ & $\mathrm{N}$ \\
\hline KMRcC2g1 & $\mathrm{N}$ & $\mathrm{N}$ & $\mathrm{N}$ & $\mathrm{N}$ & $\mathrm{N}$ \\
\hline VKRcC3g2S2R1 & $\mathrm{N}$ & $\mathrm{N}$ & $\mathrm{N}$ & $\mathrm{N}$ & $\mathrm{N}$ \\
\hline CHRcC2g1S1 & $\mathrm{N}$ & $\mathrm{N}$ & $\mathrm{N}$ & $\mathrm{N}$ & $\mathrm{N}$ \\
\hline KALcC2g1 & $\mathrm{N}$ & $\mathrm{N}$ & $\mathrm{N}$ & $\mathrm{N}$ & $\mathrm{N}$ \\
\hline MRLfC2 & $\mathrm{N}$ & S3r & $\mathrm{S} 3 \mathrm{r}$ & $\mathrm{S} 3 \mathrm{r}$ & $\mathrm{S} 3 \mathrm{r}$ \\
\hline VKRhD3g2S2R1 & $\mathrm{N}$ & $\mathrm{N}$ & $\mathrm{N}$ & $\mathrm{N}$ & $\mathrm{N}$ \\
\hline KALhD3g1S1 & $\mathrm{N}$ & $\mathrm{N}$ & $\mathrm{N}$ & $\mathrm{N}$ & $\mathrm{N}$ \\
\hline VKRcD3g2S2 & $\mathrm{N}$ & $\mathrm{N}$ & $\mathrm{N}$ & $\mathrm{N}$ & $\mathrm{N}$ \\
\hline KALhD3g1S1 & $\mathrm{N}$ & $\mathrm{N}$ & $\mathrm{N}$ & $\mathrm{N}$ & $\mathrm{N}$ \\
\hline KMRfC2 & $\mathrm{N}$ & $\mathrm{N}$ & $\mathrm{N}$ & $\mathrm{N}$ & $\mathrm{N}$ \\
\hline VKRhD3g2S2R1 & $\mathrm{N}$ & $\mathrm{N}$ & $\mathrm{N}$ & $\mathrm{N}$ & $\mathrm{N}$ \\
\hline CHRhD3g1S1 & $\mathrm{N}$ & $\mathrm{N}$ & $\mathrm{N}$ & $\mathrm{N}$ & $\mathrm{N}$ \\
\hline BHGcF3g2S2R1 & $\mathrm{N}$ & $\mathrm{N}$ & $\mathrm{N}$ & $\mathrm{N}$ & $\mathrm{N}$ \\
\hline VKRhC3g2S2R1 & $\mathrm{N}$ & $\mathrm{N}$ & $\mathrm{N}$ & $\mathrm{N}$ & $\mathrm{N}$ \\
\hline KALiC2g1 & $\mathrm{N}$ & $\mathrm{N}$ & $\mathrm{N}$ & $\mathrm{N}$ & $\mathrm{N}$ \\
\hline BHGhE3g2S2R1 & $\mathrm{N}$ & $\mathrm{N}$ & $\mathrm{N}$ & $\mathrm{N}$ & $\mathrm{N}$ \\
\hline CHThD3g1S1 & $\mathrm{N}$ & $\mathrm{N}$ & $\mathrm{N}$ & $\mathrm{N}$ & $\mathrm{N}$ \\
\hline CHTcC2g1 & $\mathrm{N}$ & $\mathrm{N}$ & $\mathrm{N}$ & $\mathrm{N}$ & $\mathrm{N}$ \\
\hline KALcC2g1 & $\mathrm{N}$ & $\mathrm{N}$ & $\mathrm{N}$ & $\mathrm{N}$ & $\mathrm{N}$ \\
\hline VKRiD3g2D3S2R1 & $\mathrm{N}$ & $\mathrm{N}$ & $\mathrm{N}$ & $\mathrm{N}$ & $\mathrm{N}$ \\
\hline CHTcD3g1S1 & $\mathrm{N}$ & $\mathrm{N}$ & $\mathrm{N}$ & $\mathrm{N}$ & $\mathrm{N}$ \\
\hline CHTcD3g2S2 & $\mathrm{N}$ & $\mathrm{N}$ & $\mathrm{N}$ & $\mathrm{N}$ & $\mathrm{N}$ \\
\hline VKRcD3g2S2R1 & $\mathrm{N}$ & $\mathrm{N}$ & $\mathrm{N}$ & $\mathrm{N}$ & $\mathrm{N}$ \\
\hline CHThD3g1S1 & $\mathrm{N}$ & $\mathrm{N}$ & $\mathrm{N}$ & $\mathrm{N}$ & $\mathrm{N}$ \\
\hline BHGhE3g2S2R1 & $\mathrm{N}$ & $\mathrm{N}$ & $\mathrm{N}$ & $\mathrm{N}$ & $\mathrm{N}$ \\
\hline CHRhD3g1 & $\mathrm{N}$ & $\mathrm{N}$ & $\mathrm{N}$ & $\mathrm{N}$ & $\mathrm{N}$ \\
\hline
\end{tabular}


Among all the eight series, Bhogapur series, Chatra series and Vaykarnala series were classified under capability class III and most of the crops like green gram, sorghum, pearl millet and guava are moderately suitable and on other hand stream bank series were classified into IV land capability class due to severe limitation of erosion (Fig. 4). Similar findings were also reported by (Leelavathi et al., 2004).

\section{Soil-site suitability evaluation for crops}

The optimum requirements of a crop are always region specific. Climate and soil-site parameters play significant role to maximize the crop yields. The soil-site properties from the study area (Table 1a and 1b) were matched with soil-site suitability criteria for different crops (Sehgal, 1966).

\section{Land suitability of horticultural crops}

The optimum requirements of a crop are always region specific. Climate and soil-site parameters play significant role in maximizing the crop yields (Sys et al., 1991).

Based on degree of limitations of soil fertility, climatic regime and land quality the soil site suitability criteria of Amarapura- 2 microwatershed classified for horticultural crops (Table 2).

\section{Mango (Mangifera indica L.)}

In most parts of the Amarapura-2 village poor soil characteristics like very shallow depth, poor drained soils, sandy loam to sandy clay loam soils, gently sloping and severe eroded characters observed.

Hence, the sustainability assessment for mango in Amarapura-2 village showed that 494 ha $(95.14 \%)$ area not suitable for mango production (Fig. 5).

\section{Sapota (Manilkara zapota L.)}

The suitability assessment for Sapota in Amarapura-2 village showed that only 7 ha (1.46) area found marginally suitable with limitations to rooting conditions. About 486 ha $(93.6 \%)$ area not suitable for Sapota production due to sensitive to poor drainage, presence of free $\mathrm{CaCO}_{3}$, high soil $\mathrm{pH}$, extreme gravel and stoniness presence in soils of Amarapura-2 Village (Fig. 6).

\section{Jamun (Syzgyium kumini L.)}

The suitability assessment for Jamun in Amarapura-2 showed that 486 ha (93.6\%) area not suitable for growing Jamun (Fig. 7). About 7 ha $(1.5 \%)$ area marginally suitable with limitation to rooting conditions.

\section{Guava (Psidium guajava L.)}

The suitability assessment for Guava in Amarapura-2 showed that 486 ha (93.68\%) area not suitable for growing Guava (Fig. 8). About 8 ha $(1.46 \%)$ area marginally suitable for guava production with limitation to rooting conditions.

\section{Custard apple (Annona reticulata)}

Amarapura-2 showed that 486 ha (93.68\%) area not suitable for growing Custard apple (Fig. 9). About 7 ha (1.46\%) area marginally suitable for custard apple production with limitation to rooting conditions. Ssimilar findings were also reported for Mango, Sapota, Jamun, Gauva, Custard apple by Maheshkumar et al., (2017).

\section{Proposed crop plan for Amarapura-2 micro-watershed}

After assessing the land suitability for five horticultural crops, a proposed crop plan has been prepared for field crops and horticultural 
crops with suitable management interventions to maximize the production in Amarapura-2 micro-watershed. The proposed crop plan is presented in Table 3.

\section{Acknowledgement}

The World Bank, Watershed Development Department, Govt. of Karnataka, Bengaluru, NBSS\&LUP, Regional Office, Bengaluru.

\section{References}

Anon.1999. Soil Taxonomy - A basic system of soil classification for making and interpreting soil surveys. Second edition. Agricultural Hand Book No. 436, United States Department of Agriculture, Washington, D.C., USA. Anonymous, 1961. Land-Capability Classification, Soil Conservation Service U.S. Department of agriculture, Agriculture handbook No. 210, pp 3-5.

FAO (1990). Watershed management field manual. In: FAO conservation Guide 13I6FAO. Rome. Italy. pp. 53-69.
Jackson, M.L., (1958). Soil Chemical Analysis. Prentice Hall, Inc., Englewod Cliffs, New Jersey.

Kharche. V. K. and Gaikawad. S. T. (199J). An appraisal of production potentials of suiis of Saongi watershed near Nagpur. Maharashtra. Agrope Joln R. 3: 69-78.

Leelavathi GP, Naidu MVS, Ramavatharam N, Karuna Sagar G (2009) Studies on genesis, classification and evaluation of soils for sustainable land use planning in yerpedu mandal of Chittor district, Andra Pradesh. Journal of Indian society of Soil Science 57:109-120.

Maheshkumar, Basavaraj K, Sharanbhoopal R, Rudramurthy HV, Rajesh NL (2017) Land evaluation of Dongaragaon microwatershed in North Eastern Dry Zone of Karnataka for Sustainable Land Use Planning. Research Journal of Agricultural Science 8(5):1110-1114

Sehgal J L (1996) Pedology - Concepts and applications. Kalyani Publishers, New Delhi. pp. 488.

Sys, C., Van Ranst, E. and Debaveye, J. (1991) Land Evaluation Part 1 \& 2, Agricultural Publication 7, Brussels, Belgium

\section{How to cite this article:}

Rajesh, N.L., U. Satishkumar, I. Shankergouda, S. N. Bhat, K. Basavaraj, H.V. Rudramurthy, K. Narayana Rao, V. Rajesh and Meenkshi Bai, R. 2018. Detailed LRI for Assessment of Land Capability and Land Suitability of Amarapura-2 Micro-Watershed Using RS and GIS. Int.J.Curr.Microbiol.App.Sci. 7(10): 2370-2381. doi: https://doi.org/10.20546/ijcmas.2018.710.274 